10IKC-243

\title{
THE BRAZILIAN KIMBERLITE-KAMAFUGITE ASSOCIATION: A NEW AND IMPROVED GEOCHRONOLOGICAL AND GEOCHEMICAL INVESTIGATION
}

\author{
M. Felgate*, D. Phillips,J. Hergt, J. Woodhead \\ School of Earth Sciences, The University of Melbourne, Parkville, 3010 Victoria, Australia
}

\section{INTRODUCTION}

The Brazilian Potassic Province provides a unique opportunity to further our understanding of kimberlite magmatism, and the Earth's deep mantle as it plays host to a number of rare, mantle derived, potassic rocks, including "transitional" kimberlites. The province provides an interesting prospect as it is the only known example of comagmatic kimberlite and kamafugite emplacement. Currently, a limited number of studies have been undertaken on the province, with the paucity most likely attributed to the highly altered nature of surface exposures and deep weathering profiles. The existing studies have all noted the potassicmagmatism is focused along a mega-lineament trending at $125^{\circ}$ spaning from Rondonia to Minas Gerais (see Fig 1). However, there is still some debate as to the emplacement mechanism of the rock types and their geochemical affinity. One theory, regarding the emplacement mechanism, proposed by a number of authors, is that continental extension related to the opening of the Atlantic caused adiabatic decompression of the lithospheric mantle, which led to partial melting and production of the variable potassic magmas along the pre-existing lineament (Bizzi et al., 1995b; Meyer et al., 1995). Alternatively, based on KArphlogopite dating, Gibson et al (1995) proposed the potassicmagmatism was caused by conductive or advective heating of the Trindade plume as it travelled under the South American continent, as age of emplacement was found to decrease from north west to south east, mirroring the movement of the Trindade plume under the South American continent $\sim 85 \mathrm{ma}$. Further support for this theory has been subsiquently offered by a study by Sgarbi et al., (2004) where U-Pb perovskite dating has shown an age progression between the kamafugites from the GAP to the APIP. A third theory has also been proposed by

Read et al (2004), using stratigraphical relationships between the kimberlites and the kamafugites of the Quirico basin, Minas Gerais, and proposes the kimberlites were emplaced prior to the kamafugites and emplacement of the two rock types were triggered by different events.

Previously studies have also focused on the geochemical relationship between the Brazilian kimberlites and kamafugites, with major attention placed on investigating their geochemical (mineral/whole rock), and isotopic relationships, (Araujo et al., 2001; Bizzi et al., 1995a; Bizzi et al., 1995b; Carlson et al., 2007; Carlson et al., 1996; Gibson et al., 1995), with a number of varying interpretations regarding their source region being suggested.

The number of varying theories regarding the emplacement mechanism and geochemical relationship between the Brazilian kimberlites and 


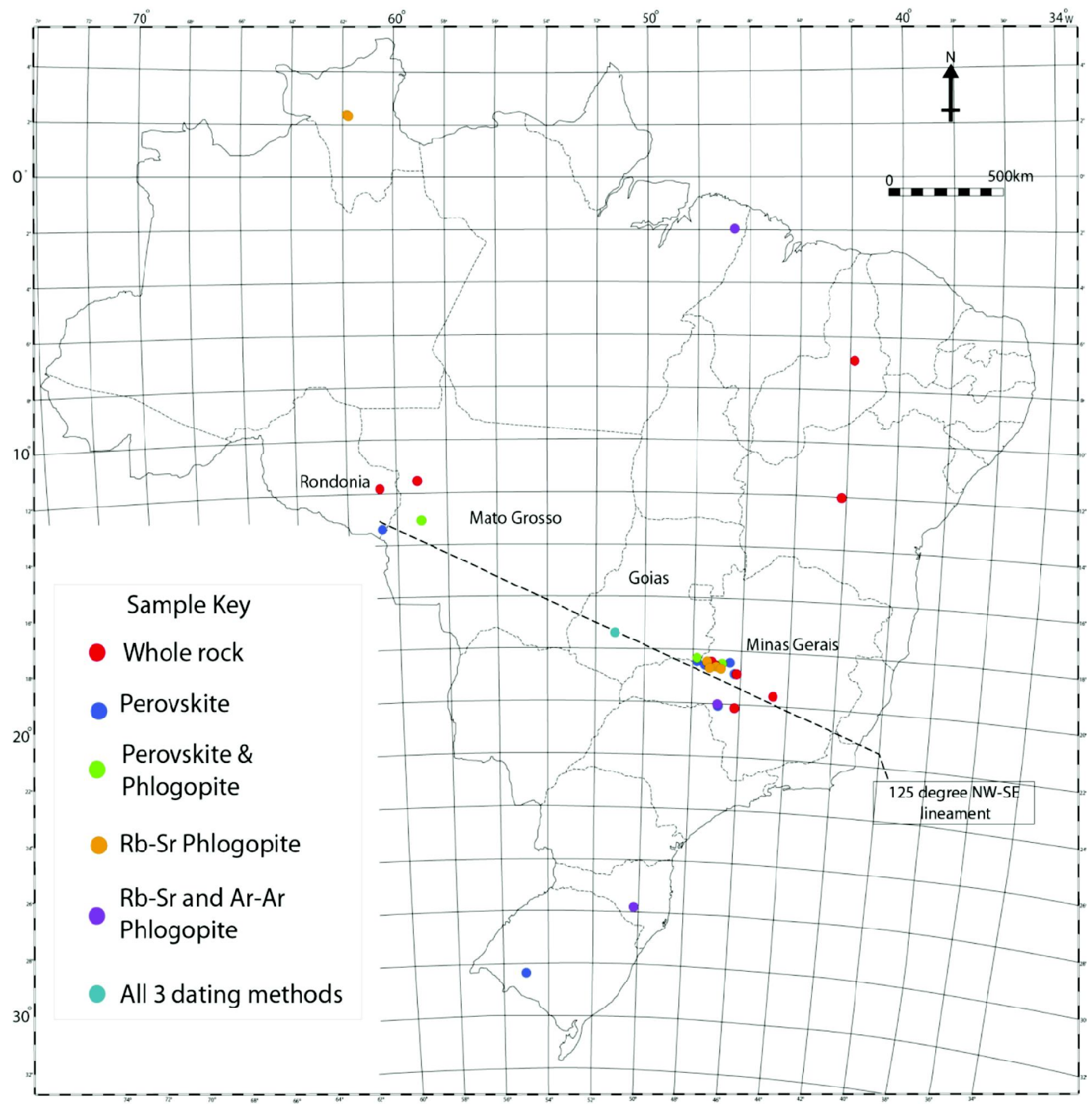

Fig 1: Locality map showing the locations of the samples for this study.

kamafugites highlight the need for further investigation. It must also be noted that the two major papers on this study area (Bizzi et al., 1995b, Gibson et al 1995) have used erroneous data and redundant dating techniques (K-Ar), respectively.
Therefore this new study has been undertaken to provide a more accurate and representative dataset, enabling some of the outstanding theories to be tested and questions answered. 


\section{0 $^{\text {th }}$ International Kimberlite Conference, Bangalore - 2012}

\section{SAMPLE SUITE}

The study consists of 52 drill core samples from 42 separate intrusions, the majority of which are located within the states of Rondonia (2 samples), MatoGrosso (2 samples), Gioas (3 Samples), and Minas Gerais (35 samples), along the $125^{\circ}$ lineament. These samples include both kimberlite and kamafugite, which have been distinguished from one another by the application of petrology and whole rock major and trace element analysis.

\section{METHODS}

The hybrid nature of kimberlite and kamafugite coupled with their often highly altered state, present major challenges when trying to evaluate bulk rock isotopic data, (Heaman, 1989; Mitchell, 1986, 1995). An alternative to whole rock isotope analysis is to analyse an early crystallising primary phase, thought to have crystallised directly from the magma. It is believed this technique has the capacity to provide a more reliable estimate of the original isotopic signature of the parental magma, (Heaman, 1989). Perovskite, (CaTiO3), is a common accessory phase found in Brazilian kimberlites and kamafugites. It is believed to form during the early stages of magmatic crystallisation and record the least contaminated or contamination-free magma, (Wu et al., 2010). Perovskite is also extremely resistant to alteration and contains high amounts of $\mathrm{Sr}(>1000 \mathrm{ppm})$, coupled with very low $\mathrm{Rb}$ $(<2 \mathrm{ppm})$, High $\mathrm{Nd}(>1000 \mathrm{ppm})$, and relatively high Hf ( 60ppm). This provides the perfect opportunity for $\mathrm{Sr}-\mathrm{Nd}-\mathrm{Hf}$ isotope studies, (Heaman, 1989; Wu et al., 2010). The high levels of Uranium in the Perovskite also make it suitable for $\mathrm{U}-\mathrm{Pb}$ dating. So the analysis of Brazilian kimberlitic perovskite should help to provide isotopic data more representative of its kimberlitic magma and its source region compared to whole rock analyses previously obtained, whilst also providing the opportunity to determine the timing of kimberlitic intrusion.

\section{GEOCHRONOLOGY}

An in depth geochronological investigation has been carried out using 3 separate techniques firstly $\mathrm{U}-\mathrm{Pb}$ analysis of perovskite grains (both solution and in situ) were employed. The in situ perovskite analysis follows the procedure reported in Wu et a,1 (2010), with a spot size ranging from 26-54 $\mu \mathrm{m}$. However, as the Brazilian kimberlites and kamafugites have a substantial amount of "common" $\mathrm{Pb}$ the technique has been developed to include a second primary phase thought to have formed at the same time as the perovskite, with much lower uranium content. This phase acts as a natural anchor point on the ${ }^{207} \mathrm{~Pb} /{ }^{206} \mathrm{~Pb}$ axis of the Terra Wasserburg diagram where it acts to extend the spread of data and provide more accurate data.

The Perovskite data is also coupled with Rb$\mathrm{Sr}$ and Ar-Arphlogopite techniques to provide a wider spread of age data as not all samples contain Perovskite. See fig 1 for information on the techniques used for each sample.

\section{ISOTOPE GEOCHEMISTRY}

This study has utilised both in-situ and isotope dilution perovskite techniques when investigating the $\mathrm{Sr}-\mathrm{Nd}$ systems whilst also employing the isotope dilution technique to investigate $\mathrm{Hf}$ isotopic system. The isotope dilution analysis has also been used to cross reference the results obtained via laser ablation to further validate the in-situ technique. The in situ $\mathrm{Rb}$ procedure is the same as reported by Paton et al (2007b) with a spot size varying between $26-54 \mu \mathrm{m}$, depending on grain size. Whereas the $\mathrm{Nd}$ procedure is that reported by Yang et al., (2009), again utilising a spot size ranging between $26-54 \mu \mathrm{m}$. 


\section{0 $^{\text {th }}$ International Kimberlite Conference, Bangalore - 2012}

\section{RESULTS}

\section{Isotopic}

Preliminary perovskite $\mathrm{Rb}-\mathrm{Nd}$ isotope analysis have places both kimberlite and kamafugite in the transitional field, with kimberlitesSr (i) $\sim 0.705$ and kamafugiteSr (i) $\sim 0.706$, although there is a slight overlap between the two rock types.

\section{Geochronological}

Preliminary data shows a small age progression from NW-SE in the Rb-Srphlogopite and $\mathrm{U}-\mathrm{Pb}$ perovskite ages along the lineament between Goias and Minas Gerais. In the samples which contain both phlogopite and perovskite, both ages correspond within error. One sample in the Rondoniastate produced a U-Pbage of $267 \pm 3 \mathrm{Ma}$ which corresponds well with the findings of Masun and Smith(2008), who report a kimberlite from the same state with an age of 230ma.

\section{OVERVIEW}

The implementation of all these techniques to the new sample suite have provided the opportunity to gain a greater understanding of the relationship between these two rock types whilst also allowing improvement of the perovskite U$\mathrm{Pb}$ geochronological technique.

\section{References}

Araujo, A.L.N., Carlson, R.W., Gaspar, J.C., and Bizzi, L.A., 2001, Petrology of kamafugites and kimberlites from the Alto Paranaiba Alkaline Province, Minas Gerais, Brazil: Contributions to Mineralogy and Petrology, v. 142, p. 163-177.

Bizzi, L.A., 1995, Mesozoic alkaline volcanism and mantle evolution of the Southwestern Sao Francisco craton, Brazil: Cape Town, University of Cape Town.
Bizzi, L.A., Dewit, M.J., Smith, C.B., McDonald, I., and Armstrong, R.A., 1995a, HETEROGENEOUS ENRICHED MANTLE MATERIALS AND DUPAL-TYPE MAGMATISM ALONG THE SW MARGIN OF THE SAO-FRANCISCO CRATON, BRAZIL: Journal of Geodynamics, v. 20, p. 469491.

Carlson, R.W., Araujo, A.L.N., Junqueira-Brod, T.C., Gaspar, J.C., Brod, J.A., Petrinovic, I.A., Hollanda, M., Pimentel, M.M., and Sichel, S., 2007, Chemical and isotopic relationships between peridotite xenoliths and mafic-ultrapotassic rocks from Southern Brazil: Chemical Geology, v. 242, p. 415434.

Carlson, R.W., Esperanca, S., and Svisero, D.P., 1996, Chemical and Os isotopic study of cretaceous potassic rocks from southern Brazil: Contributions to Mineralogy and Petrology, v. 125, p. 393-405.

Gibson, S.A., Thompson, R.N., Leonardos, O.H., Dickin, A.P., and Mitchell, J.G., 1995, THE LATE CRETACEOUS IMPACT OF THE TRINDADE MANTLE PLUME - EVIDENCE FROM LARGE-VOLUME, MAFIC, POTASSIC MAGMATISM IN SE BRAZIL: Journal of Petrology, v. 36, p. 189-229.

Heaman, L.M., 1989, THE NATURE OF THE SUBCONTINENTAL MANTLE FROM SR-NDPB ISOTOPIC STUDIES ON KIMBERLITIC PEROVSKITE: Earth and Planetary Science Letters, v. 92, p. 323-334.

Li, Q.L., Li, X.H., Liu, Y., Wu, F.Y., Yang, J.H., and Mitchell, R.H., 2010, Precise U-Pb and Th-Pb age determination of kimberlitic perovskites by secondary ion mass spectrometry: Chemical Geology, v. 269, p. 396-405

Masun, K.M., and Smith, B.H.S., 2008, The PimentaBuenokimberlite field, Rondonia, Brazil: Tuffisitickimberlite and transitional textures: Journal of Volcanology and Geothermal Research, v. 174 , p. $81-89$.

Meyer, H.O.A., Garwood, B.L., Svisero, D.P., and Smith, C.B., 1995, Alkaline ultrabasic intrusions in Western Minas Gerais, Brazil, Proceedings of the 5 th international kimberlite conference, Volume 1: Brazil, p. 140-156.

Mitchell, R.H., 1972, COMPOSITION OF PEROVSKITE IN KIMBERLITE: American Mineralogist, v. 57, p. 1748-1753. 


\section{0 $^{\text {th }}$ International Kimberlite Conference, Bangalore - 2012}

—, 1986, Kimberlites: Mineralogy, Geochemistry, and Petrology, Plenum Press, New York, 442 p.

_, 1995, Kimberlites, Orangeites, and Related Rocks, Plenum Press, New York, 410 p.

_, 1997, Kimberlites, Orangeites, Lamproites, Melilitites, and Minettes: A Petrographic Atlas, Almaz Press, Thunder Bay, Ontario, Canada, 234 p.

Mitchell, R.H., Wu, F.-Y., and Yang, Y.-H., 2011, In situ $\mathrm{U}-\mathrm{Pb}, \mathrm{Sr}$ and $\mathrm{Nd}$ isotopic analysis of loparite by LA-(MC)-ICP-MS: Chemical Geology, v. 280, p. 191-199.

Paton, C., 2007, The Peterogenesis of Indian Kimberlite Magmas: A geochemical and geochronological investigation into kimberlite intrusions from the Dharwarcraton, India: Melbourne, University of Melbourne.

Paton, C., Hergt, J.M., Phillips, D., Woodhead, J.D., and Shee, S.R., 2007a, New insights into the genesis of Indian kimberlites from the DharwarCraton via in situ $\mathrm{Sr}$ isotope analysis of groundmass perovskite: Geology, v. 35, p. 10111014.

Paton, C., Woodhead, J.D., Hergt, J.M., Phillips, D., and Shee, S., 2007b, Strontium isotope analysis of kimberlitic groundmass perovskite via LA-MCICP-MS: Geostandards and Geoanalytical Research, v. 31, p. 321-330.

Read, G., Grutter, H., Winter, S., Luckman, N., Gaunt, F., and Thomsen, F., 2004, Stratigraphic relations, kimberlite emplacement and lithospheric thermal evolution, Quirico basin, Minas Gerais state, Brazil: Lithos, v. 77, p. 803-818.

Sgarbi, P.B.A., Heaman, L.M., and Gaspar, J.C., 2004, $\mathrm{U}-\mathrm{Pb}$ perovskite ages for Brazilian kamafugitic rocks: Further support for a temporal link to a mantle plume hotspot track: Journal of South American Earth Sciences, v. 16, p. 715-724.

Wu, F.Y., Yang, Y.H., Mitchell, R.H., Li, Q.L., Yang, J.H., and Zhang, Y.B., 2010, In situ U-Pb age determination and $\mathrm{Nd}$ isotopic analysis of perovskites from kimberlites in southern Africa and Somerset Island, Canada: Lithos, v. 115, p. 205222.

Yang, Y.H., Sun, J.F., Xie, L.W., Fan, H.R., and Wu, F.Y., 2008, In situ Nd isotopic measurement of natural geological materials by LA-MC-ICPMS: Chinese Science Bulletin, v. 53, p. 1062-1070. 